\title{
Study of the Behavior of Some Spring Barley Lines with Two Rows Created at A.R.D.S Turda Regarding Production Capacity and Quality
}

\author{
Ioana PORUMB ${ }^{1,2}$, Florin RUSSU ${ }^{2}$ \\ ${ }^{1}$ University of Agricultural Sciences and Veterinary Medicine Cluj-Napoca, Romania \\ ${ }^{2}$ Agricultural Research and Development A.R.D.S Turda, Romania \\ *Corresponding author: ioanaporumb18@yahoo.com
}

Bulletin USAMV series Agriculture 74(1)/2017

Print ISSN 1843-5246; Electronic ISSN 1843-5386

DOI 10.15835/buasvmcn-agr: 12656

\begin{abstract}
The spring barley is a variety of a superior quality for brewing compared with the feed barley due to several reasons. Research was conducted in the field of breeding of spring barley with two rows, within ARDS Turda, during 2013-2015. The trials were comparatively developed, and included 25 variants. The biological material was represented by four autochthonous genotypes: Turdeana, Daciana Romaniţa (A.R.D.S. Turda), and Adina (A.R.D.S. Suceava). The spring barley lines created by the S.C.D.A. Turda, meet the requirements of the beer industry in terms of protein content, starch, M.M.B. and germination energy.
\end{abstract}

Keywords: barley, TKW, starch, proteine, yield.

\section{INTRODUCTION}

The spring barley is of a superior quality for brewing compared with the feed barley for several reasons, namely: spring barley grains are larger and more uniform, produce a better quality malt, husk with cloth spring barley grains are finer and more pursed, which enhances their role filter, spring barley grains have a lower protein content and rich in starch, which means better quality for brewing (ION, 2010). Within A.R.D.S. Turda and Suceava, also autochtonous genotypes are developed. Among these we mention three genotypes obtained at A.R.D.S. Turda (Turdeana, Daciana and Romaniţa), and Adina genotype, which was obtained at A.R.D.S. Suceava.

\section{MATERIALS AND METHODS}

Researches which constitutes the study of this paper were conducted in the field of breeding of spring barley with two rows, within ARDS Turda. The experimental period lasted during the years 2013-2015. The trials were comparatively developed, and included 25 variants. The biological material was represented by autochthonous genotypes, Turdeana (control), and Jubileu 1 with specific lines. The rest lines are obtained as consequence of the hybridization work, followed by repeated individual selection. In relation to proposed objectives, these lines were assessed for: production and stability, protein content and starch in two years $(2014,2015)$. The aim of these experiments is to identify the most valuable lines suitable for brewing or animal feed.

\section{RESULTS AND DISCUSSIONS}

In a comparative culture of competition were tested 25 variants of spring barley in order to identify lines with high yield potential, which can 


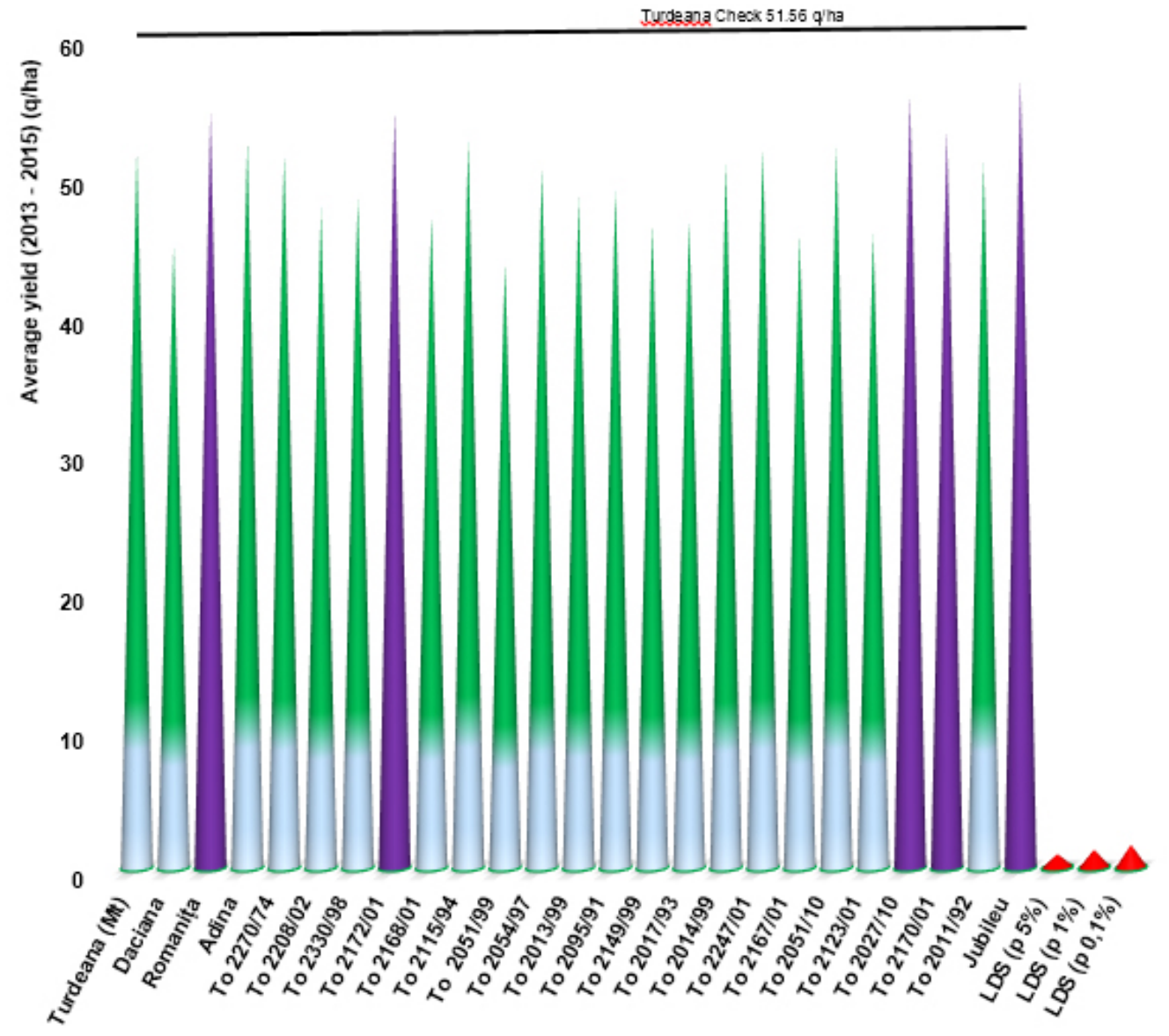

Genotypes

Figure 1. Average yield a lines of spring barley with two rows in comparative culture of competition created to A.R.D.S. Turda (2013 - 2015)

be exploited primarily in the brewing industry, and those less suitable for the industry brewing (low content the protein- under $12.5 \%$, a percentage higher than $60 \%$ starch and high germination energy over 95\%) but with a good production capacity which may be used for animal feed. The lines that have shown a superior response on these aspects, are going to be to be tested by ISTIS network for homologation.

In Fig. 1 can be seen the average high production potential of the 25 variants, between 43 and $56 \mathrm{q} /$ ha.

The Duncan test, applied to the studied Jubileu 1 genotype comes first, followed by To $2027 / 10$ line and third and four are To 2172/01 line, To 2170/01 and Romanița genotype.
The protein content of the variants studied in two experimental years is shown in Fig. 2, can be seen the influence year the accumulation of proteins so that in 2015 all genotypes recorded higher values compared to 2014. However not exceeded the maximum permitted levels for the brewing industry namely $12.5 \%$ excluding line To 2011/92.

Another important requirement for brewing is the starch which our research shows, is that it has values close of requirements breweries about $60 \%$.

In 2014 when there were low levels of protein content as was expected values mean starch were higher content in 2015 namely 55.14\%. To2054/ 97 line can be observed with the highest starch 


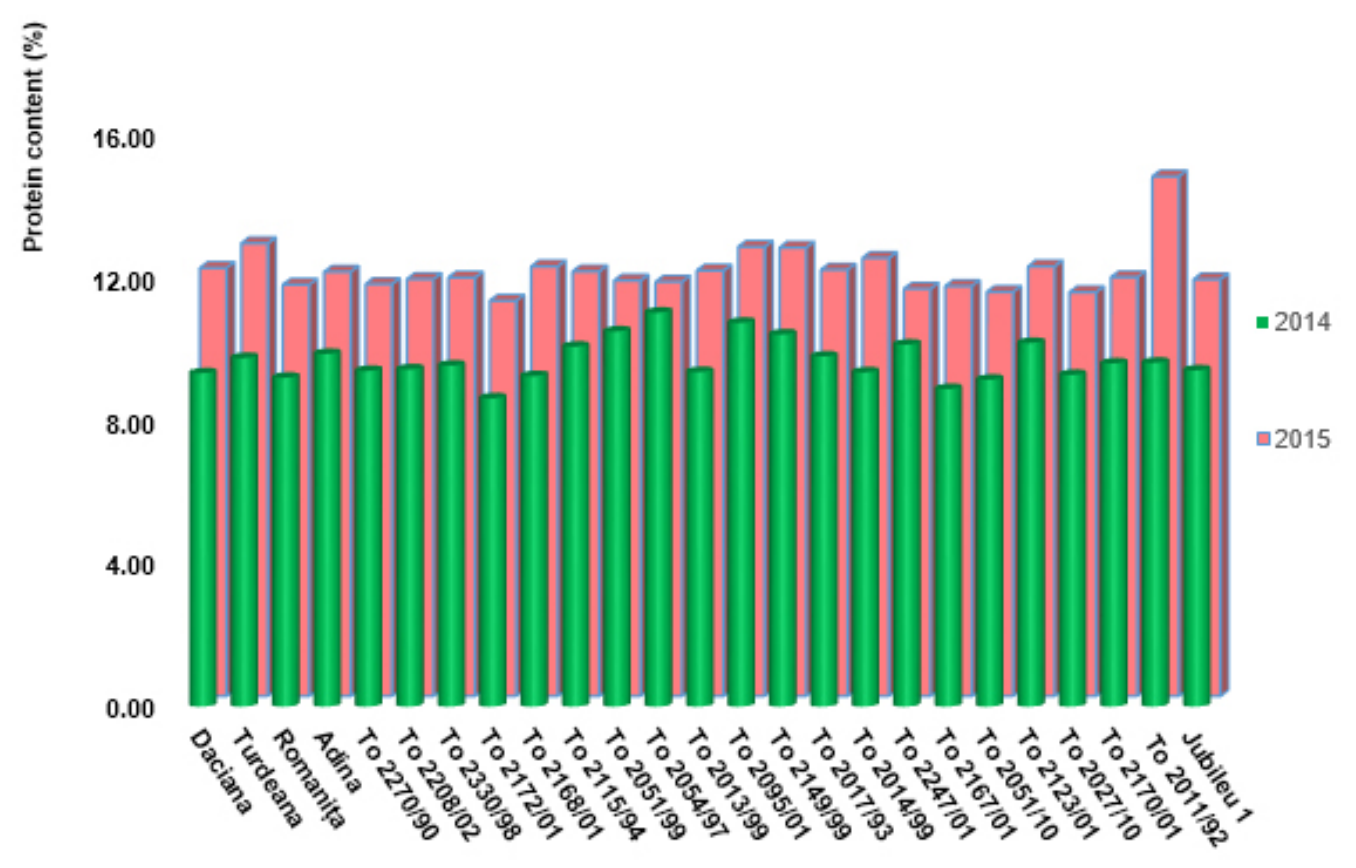

Genotypes

Figure 2. The protein content in the 25 variants studied in 2014, 2015

content of $56.32 \%$ and Jubileu 1 genotype with values close to about $56 \%$.

\section{CONCLUSION}

The conclusion drawn from the above data, is that spring barley lines created by the S.C.D.A. Turda, meet the requirements of the beer industry in terms of protein content, starch, M.M.B. and germination energy.

The main objective of improvement it still remains the production and stability of spring barley, and on this aspect Jubileu 1 and To 2027/10 lines are suitable and they will proposed to be tested for homologation.

\section{REFERENCES}

1. Francis TR, Kannenberg LW (1978). Yield stability studies in short season maize. I. A descriptive method for grouping genotypes. Can. J. Plant Sci. 58:1029-1034.

2. Ion V. (2010). Fitotehnie http://www-horticulturabucurești.ro.

3. Vasilescu L, Alionte E, Bude A ( 2014). Comportarea unor soiuri şi linii de orz de toamnă la I.N.C.D.A. Fundulea în perioada 2008-2013, sub aspectul stabilităţii producției şi calităţii. Genetica şi ameliorarea plantelor. An. I.N.C.D.A. Fundulea, vol. LXXXII, 2014. http://www.incda-fundulea. ro/anale/82/ 82.7.pdf

4. Taner A, Muzaffer A, Dusunceli F (2004). Barley: Post Harvest Operations. Edited by AGST/FAO: Danilo Meja, Phd, FAO Technical. 